\title{
CORPORATE SOCIAL RESPONSIBILITY IN THE SYSTEM OF INTERACTION BETWEEN STAKEHOLDERS OF CONSTRUCTION ENTERPRISES
}

\author{
Volodymyr Velychko', Dmytro Prunenko², Evgeniy Grytskov³
}

\begin{abstract}
It is proved that at the present stage of economic transformation, the problem of ensuring the effectiveness of interaction with stakeholders, which affect all areas of business entities is exacerbated. The cooperation of stakeholders to ensure corporate social responsibility at construction enterprises is of particular importance and requires solving the problems of the formation and implementation of corporate social responsibility in the system of interaction between stakeholders of construction enterprises. As a result of the analysis of existing scientific and methodological works, the need for the formation and implementation of corporate social responsibility in construction enterprises is determined, considering the peculiarities of interaction with stakeholders. The aim of the study is the formation of measures for the creation and implementation of corporate social responsibility at construction enterprises, considering the areas of interaction with stakeholders.

The article solves the tasks of identifying stakeholders interacting with construction enterprises, substantiating theoretical approaches to determining corporate social responsibility of construction enterprises, assessing the level of influence of corporate social responsibility on the functioning of construction enterprises, taking into account the peculiarities of interaction with stakeholders .

The indicators that form corporate social responsibility are identified, and the corresponding integral indicator is evaluated, which allows us to create a quantitative basis for making informed management decisions. The necessity of developing measures to increase the efficiency of the formation and use of corporate social responsibility at construction enterprises is established.

The subject of the study is corporate social responsibility in the system of stakeholder relations of construction companies.

The formation of the research methodology is based on the definition of stakeholders and corporate social responsibility, the use of classification (to form and determine stakeholder factors affecting corporate social responsibility of construction companies), analytical and expert evaluation method (to assess the general criterion of stakeholders' impact on corporate social responsibility construction companies).

The purpose of the study is to form a quantitative basis for making sound management decisions on the formation and use of corporate social responsibility in the system of stakeholder relations of construction companies.

The result of the study is to determine the directions and features of increasing the effectiveness of the formation and use of corporate social responsibility in construction companies in the system of stakeholder relations, which are developed based on the results of assessing the generalized criterion of stakeholder interaction on corporate social responsibility.
\end{abstract}

Key words: stakeholders, corporate social responsibility, construction enterprises, corporate relations.

JEL Classification: C43, C65, D03, D22, L74

\footnotetext{
Corresponding author:

${ }^{1}$ O. M. Beketov National University of Urban Economy in Kharkiv, Ukraine.

E-mail: hcsms.07@gmail.com

ORCID: https://orcid.org/0000-0002-0282-368X

${ }^{2}$ O. M. Beketov National University of Urban Economy in Kharkiv, Ukraine.

E-mail: dmytro.prunenko@kname.edu.ua

ORCID: https://orcid.org/0000-0001-7322-9998

${ }^{3}$ O. M. Beketov National University of Urban Economy in Kharkiv, Ukraine.

E-mail: grytskov@kh.gov.ua

ORCID: https://orcid.org/0000-0003-4766-7155
} 


\section{Introduction}

At the present stage of economic transformation, the problem of ensuring the effectiveness of interaction with stakeholders is becoming more acute. They affect all areas of the functioning of business entities. Stakeholders form relationships in the supply of inventory, production, and sale of products, the creation and use of social and corporate policies. Stakeholders significantly influence the activities and development of construction enterprises. Moreover, the interaction of stakeholders in ensuring corporate social responsibility at construction enterprises is of particular importance. In such circumstances, solving the problems of the formation and implementation of corporate social responsibility in the system of interaction between stakeholders of construction enterprises is an urgent and timely task. In existing scientific developments, theoretical provisions have been identified and justified to ensure the cooperation of stakeholders with enterprises (E. Freeman (1984), P. D’Anselmi (2011), A. Ammar (2012), L. Gatsenko (2016), D. Cleland (1998), A. Nepomnyashchy (2013), V. Suslov (2011), N. Slyusarevsky (2010).

The attention of scientists and practitioners is focused on corporate social responsibility. In particular, the International Standard ISO 26000: 2010 "Guidelines on Social Responsibility" defines that corporate social responsibility is characterized as the organization's responsibility for the impact of its decisions and activities on society and the environment through transparent and ethical behavior, which in turn is compatible with sustainable development and wellbeing of society, considering the expectations of stakeholders (International standard ISO 26000:2010, 2010). The principles of corporate social responsibility are defined: accountability, transparency, ethical behavior, ensuring the interests of stakeholders, and the rule of law, compliance with international norms of behavior, and human rights. In accordance with International Standard ISO 26000, stakeholders are organizations or individuals whose one or more interests relate to any decision or activity of the organization (International standard ISO 26000:2010, 2010). Problems of corporate social responsibility have been studied in Kotler and Lee (2005), Bowen (1953), Friedman (2010), Plakasov (2012), Chernykh (2012), Hrytsyna (2008), Grishnova (2011).

Despite a significant amount of scientific works on the interaction of stakeholders, the formation of corporate social responsibility, questions regarding its creation at construction enterprises remain unresolved, considering the peculiarities of relationships with stakeholders. The article aims to develop measures for the creation and implementation of corporate social responsibility on construction enterprises, considering the directions of the interaction with stakeholders. According to the goal, the following tasks were solved:
- to identify stakeholders interacting with construction enterprises;

- to substantiate theoretical approaches to the definition of corporate social responsibility of construction enterprises;

- to assess the level of corporate social responsibility influence on the functioning of construction enterprises, considering the peculiarities of interaction with stakeholders.

\section{Materials and methods}

When substantiating the general provisions for the definition of stakeholders, they are characterized as groups, organizations, and individuals. Stakeholders, on the one hand, affect the development of the company, and on the other hand, the company affects their formation and use, determines the relationship between them. The interaction between stakeholders is carried out in the field of creation, use, and distribution of all types of resources, information support, risk, brand equity to ensure the development of construction enterprises (Mamonov, 2013). To ensure corporate social responsibility, groups of stakeholders are identified (Table 1).

Thus, as a result of the study, it was found that in existing scientific approaches, stakeholders are grouped by participation in the production process, relationship and interaction with the company in the internal and external environment, location in the company, level of influence on the enterprise, creation of possible threats and cooperation, attitude towards authority, the legality of action and application of relevant requirements. The presented grouping criteria indicate that the relationship between the stakeholders covers various areas of company activity, which requires an analysis of stakeholders to make informed management decisions in the context of developing and implementing a valuebased strategy for managing capital and brand of construction enterprises. Summarizing the above, the study identified the following groups of stakeholders:

1. Investors of the company: shareholders, domestic investors, foreign investors.

2. Managers of different levels: company owners, top managers, department heads, heads of other organizational structures.

3. Company personnel: personnel providing enterprise management, production personnel, marketing personnel, warehouse personnel, other personnel involved in the production and economic activities.

4. Company partners: suppliers of material values, dealers, consumers.

5. Social groups: public organizations, nongovernmental foundations, human rights defenders, public control bodies, trade union organizations, and other social groups. 
Table 1

The analysis of approaches to determine the groups of stakeholders

\begin{tabular}{|c|c|c|c|}
\hline No & Author(s), sources & Identification of stakeholder groups & Grouping criteria \\
\hline 1 & $\begin{array}{l}\text { National Commission } \\
\text { on Securities and Stock } \\
\text { Market } \\
\text { (Mamonov K.A., 2011) }\end{array}$ & $\begin{array}{l}\text { shareholders potential investors; lenders; counterparties to transactions; } \\
\text { other persons who have shown interest in receiving relevant information }\end{array}$ & $\begin{array}{l}\text { by participation in industrial and } \\
\text { economic activities }\end{array}$ \\
\hline 2 & $\begin{array}{c}\text { Nikitina } \\
(2013)\end{array}$ & $\begin{array}{l}\text { shareholders (participants), employees, management, creditors, } \\
\text { consumers, local community, public authorities, and administration }\end{array}$ & $\begin{array}{l}\text { by influence, strength, and interest } \\
\text { in the production and economic } \\
\text { activities of the company }\end{array}$ \\
\hline 3 & $\begin{array}{c}\mathrm{Zub} \\
(2002)\end{array}$ & $\begin{array}{l}\text { shareholders; institutional investors; senior managers; workers; } \\
\text { consumers; distributors; suppliers; corporation financiers; } \\
\text { representatives of state and municipal authorities; social and community } \\
\text { groups }\end{array}$ & $\begin{array}{l}\text { by the interests arising from the } \\
\text { interaction of stakeholders }\end{array}$ \\
\hline 4 & $\begin{array}{l}\text { Clarkson } \\
(1995)\end{array}$ & $\begin{array}{l}\text { the first group: shareholders, owners, workers, partners, etc. (direct contact } \\
\text { with the company); second group: central authorities, local govern- } \\
\text { ments, public organizations, mass media, etc. (indirect communication) }\end{array}$ & $\begin{array}{l}\text { by the nature of the relationship } \\
\text { with the company }\end{array}$ \\
\hline 5 & Blair, Fotler (1990) & external, "borderline”, internal & by location in the company \\
\hline 6 & $\begin{array}{l}\text { Savage, Nix, } \\
\text { Whitehead, Blair } \\
\text { (1991) }\end{array}$ & $\begin{array}{l}\text { stakeholders for cooperation with a high level of threat; dangerous } \\
\text { stakeholders with a low level of cooperation and a high level of risks; } \\
\text { favorable stakeholders with a high level of cooperation and with a low } \\
\text { level of threats; stakeholders with low levels of cooperation and threats }\end{array}$ & $\begin{array}{l}\text { by the level of threats and } \\
\text { opportunities for cooperation }\end{array}$ \\
\hline 7 & $\begin{array}{l}\text { Mitchell, Agley, Wood } \\
\text { (1997) }\end{array}$ & latent, pending, categorical stakeholders & $\begin{array}{l}\text { by the level of attitude to power, } \\
\text { the legality of actions, urgency of } \\
\text { requirements. }\end{array}$ \\
\hline
\end{tabular}

6. Credit institutions: banks, credit unions, other financial institutions.

7. Public administration bodies: central public administration bodies, regional public administration bodies, local self-government bodies, fiscal bodies, other public administration bodies (Mamonov, 2013).

It should be noted that each of the presented stakeholder groups affects the activities of the construction enterprise and its management. In particular, investors and managers of various levels directly influence the functioning of the construction industry enterprises and their management. The development of construction enterprises is significantly influenced by company staff and partners. Besides, the operation of the enterprises of the construction industry and the peculiarities of their management are due to interaction with government bodies and credit institutions. A group of stakeholders, which indirectly affects the functioning of construction enterprises, is the social group, whose role has been growing in recent years in the context of building a civil society. However, in some cases, the opinion of public organizations in the field of construction is ignored, as evidenced by the growing number of residential buildings and structures, the development of which is not agreed with the public (Mamonov, 2013).

Thus, certain groups allow us to analyze the characteristics of the interaction of stakeholders with construction enterprises to develop and implement a strategy of value-oriented brand capital management. In the context of ensuring corporate social responsibility of construction enterprises, models of managing stakeholders are proposed. In existing research, the following stakeholder models are highlighted.

The model of Mitchell, Agle, and Wood is aimed at identifying stakeholders, determining their impact on the enterprise, significance based on objective, qualitative and quantitative characteristics. Within the framework of the presented model, the influence of stakeholders on the management of enterprises, their authority, legitimacy of actions, the urgency of requirements is characterized. According to the presented characteristics, groups of stakeholders are determined. The advantage of the Mitchell, Agle, and Wood model is the assessment of the significance and influence of stakeholder groups in accordance with specific characteristics, which allows making management decisions, considering the interests of each of the stakeholders interacting with enterprises. However, within the framework of the presented model, the interests of stakeholders may not be considered in accordance with the given characteristics. At the time of the study, stakeholders were not interacting with the enterprises. As a result, possible transformations in the internal and external environments in the future are determined.

The balance model of resource relations is characterized by the definition of stakeholders based on relationships related to the formation, distribution, use of resources to ensure the growth of the effectiveness and efficiency of stakeholder activities. As a result of using the balance model of stakeholder management, the state is determined, and the features of the relationship on 
the distribution and use of resources in the relationship between stakeholders are identified. Besides, within the framework of the presented model, the corresponding balance of formation and use of resources is built. Based on this balance, there is an opportunity to make management decisions on the resource provision of relations between stakeholders. However, the balance model does not solve the problem of assessing the corresponding resource from the perspective of different stakeholders, which introduces various aspects when making management decisions.

The network model allows us to represent the relationship between stakeholders in the form of networks. Within the framework of the presented model, indicators of the density and centrality of stakeholder relationships are determined based on the characteristics of their accessibility and importance. The network model allows you to visually assess the status and features of the relationships between stakeholders and build a holistic system for managing these relationships, which creates the basis for managerial decisions. However, within the framework of the presented model, it is necessary to consider the maximum number of connections, which complicates the possibilities of its construction. Besides, the network model excludes intermediaries, which in today's business environment is a complex process, as these entities play a significant role in ensuring interaction between stakeholders.

In the formation and maintenance of relationships in the practice of company management between stakeholders, two main approaches are used: AngloSaxon and Japanese-German. The Anglo-Saxon approach is characterized by the determination of priority areas related to the satisfaction of the interests of shareholders (owners) to which priority is given. Within the framework of the presented approach, the primary attention is paid to ensuring an increase in the economic effect (profit growth) for shareholders, creating opportunities for further investment in the company. Using this approach allows to consider the interests of shareholders (owners) and to ensure the involvement of new stakeholders and thereby obtaining additional investment capital. Besides, the Anglo-Saxon approach implements the principle of availability, completeness, and reliability of information support for interaction with shareholders and enterprises. However, the presented approach creates specific imbalances in the relationship between stakeholders, due to the interests of shareholders (owners) over the interests of other stakeholders, reducing the motivational component of the activities and interest of different stakeholders in the results (staff, partners, etc.), as the priority of the distribution of financial resources is shifted towards shareholders (owners). Moreover, in the Anglo-Saxon approach, much attention is paid to solving tactical tasks aimed at obtaining a negative profit while reducing the role of strategic planning.

The Japanese-German approach to corporate governance when interacting with stakeholders is to ensure partnership with a wide range of stakeholders, taking into account their interests. In the process of providing interaction between stakeholders, the interests of each of them are equal without the domination of any of the stakeholders over others. Besides, the implementation of the principle of social partnership for solving relevant problems, especially in the field of employment and the achievement of social standards is of particular importance.

Within the framework of the proposed approach, it is possible to balance the interests of stakeholders, solve problematic aspects related to the social sphere, and provide for the collegial management principle in the implementation of control functions by relevant stakeholders. However, the Japanese-German approach provides for the limitation of information on the remuneration of owners and shareholders, members of the supervisory board, the use of additional stakeholders (for example, depository banks) when disseminating information, undervaluation of the company due to retained earnings. Besides, the Japanese-German approach creates conditions aimed at a specific limitation of the rights of shareholders as a result of limiting the number of votes when voting at a general meeting.

Thus, in current business conditions, with the revealed discrepancies and contradictions in the presented management approaches, there is interpenetration and interaction between the provisions and functions of the Anglo-Saxon and Japanese-German approaches. Given the transformations taking place in the domestic economy, it is impossible to completely suggest the use of the presented approaches (Mamonov, 2013).

To ensure corporate social responsibility at construction enterprises, it is proposed to take action to form and use the information and analytical support: - creation of an integrated system for assessing information threats and prompt response to them; - improving the powers of state regulatory bodies operating in the information space of the state;

- legislative regulation of the mechanism of detection, fixation, blocking, and removal from the information space;

- determination of mechanisms for regulating the work of enterprises providing information support;

- creation and development of structures responsible for informational and psychological security;

- development and protection of the technological infrastructure for ensuring information security;

- building an effective system of strategic communications;

- development of mechanisms of interaction between enterprises and civil society institutions (Doctrine of information security of Ukraine, 2017); 
- directions for the formation of technical information protection, which are characterized by the definition and analysis of threats, the development of an information protection system; implementation of an information security plan; monitoring the functioning and management of the information security system (SSSCIP);

- directions for the implementation of technical protection of information are determined by the implementation of a single technical policy; the creation and development of a single terminological system; the formation of multi-level information protection systems based on mutually agreed provisions, rules, procedures, requirements and norms; development and implementation of certification, licensing and certification systems in accordance with information security requirements; development of services in the system of technical information protection; the establishment of the procedure for the development, manufacture, operation of means of ensuring technical protection of information and special instrumentation; the organization of the design of construction work in terms of ensuring technical protection of information; the development of human capital in the system of technical protection of information;

- impact on the channels information leakage is carried out based on the formation and implementation of technical measures to block information leakage through various groups of stakeholders interacting in the formation and use of intellectual capital of construction enterprises, radio channels, acoustic, electrical, visualoptical and material channels;

- individual technical information protection includes systems for delimitation and access to information, personalization systems, identification and authenticity systems, audit and monitoring systems, antivirus protection systems;

- communicative information protection systems are formed and implemented based on the use of tools to block information attacks from the external and internal environment of the construction enterprise (Cisco PIX Firewall, Symantec Enterprise Firewall TM, Contivity Secure Gateway and Alteon Switched Firewall - Nortel Networks); technical means from unauthorized and unreasonable influence on information flows and networks (CiscoSecure IDS, IntruderAlert and NetProwler - Symantec); tools for creating secure channels by building virtual private networks (Symantec Enterprise VPN, Cisco IOS VPN, Cisco VPN concentrator); means of detecting sources of information danger, analysis of areas of information threats (Symantec Enterprise Security Manager, Symantec NetRecon);

- comprehensive software and hardware information protection tools include: protection against unauthorized access to information about the formation and use of intellectual capital of construction enterprises (authorization tools, mandatory access control, access control by defining roles, selective access control, information audit); tools for analysis and modeling of external and internal information flows (CASEsystem); monitoring tools of information protection; tools for protecting the sources of confidentiality information (DLP-systems); instrument analysis tools; antivirus products; internetworking tools for information protection; cryptographic tools for digitizing information and applying digital signatures; tools for backing up information, creating a failover cluster; uninterruptible power tools (UPS, redundant power lines, power generators); tools based on the development and implementation of passwords, access key, certificates, biometric data; security tools developed based on the use of means of protection against physical and information breaking into premises and information systems, monitoring and control for access to information, analysis tools for protection systems;

- counteraction to information confrontation is characterized by the use of tools to protect against the impact on the systems of formation, processing, dissemination and storage of enemy information, application of measures to protect information systems from external and internal threats;

- the prevention or counteraction to information wars is characterized by the formation of a system and the use of integrated tools to influence the enemy's information environment to ensure informational benefits;

- counteraction to violations of the system of formation and use of information is carried out by identifying and applying information technical tools and organizational forms: illegal collection, storage, processing, dissemination of information;

- concealment of information; untimely provision of information; distortion, dissemination of unreliable information; use of information of socially harmful content; illegal access to information of a confidential nature; use of information with limited access; the implementation of a destructive information impact on human consciousness; creation, use, distribution of malicious software; illegal access, use of processing systems, storage, the transmission of information; unauthorized interference, obstruction of the work of information and telecommunication systems and their components.

Considering the theoretical and methodological approaches to the definition of corporate social responsibility, the ambiguity of the provisions is established. In particular, the European Commission has defined corporate responsibility as a concept that reflects the company's voluntary decision to participate in improving society and protecting the environment.

In accordance with the International Standard ISO 26000: 2010 "Guidelines for Social Responsibility," areas of corporate social responsibility are defined: 
1. Development and implementation of an organizational social responsibility system to ensure interaction with stakeholders.

2. Formation and implementation of corporate governance in the system of social responsibility.

3. Ensuring labor relations in the system of social responsibility.

4. Creation of ecological relationships in the system of social responsibility.

5. Definition of conscientious business practices in the system of social responsibility.

6. Ensuring interaction with consumers (customers) in the system of social responsibility.

7. Formation of cooperation on the creation of marketing relations in accordance with social responsibility.

8. Ensuring consumer health and safety.

9. Ensuring sustainable consumption in the system of social responsibility.

10. Service and support for consumers, dispute and claims resolution.

11. Protecting information and ensuring the confidentiality of consumers.

12. Development and interaction with the community in the system of social responsibility.

13. Employing the system of social responsibility.

14. Formation of modern technologies in the system of social responsibility.

15. Creation of welfare and income in the system of social responsibility.

16. Creation of a healthy lifestyle in the system of social responsibility.

17. Realization of social investments in the system of social responsibility.

18. Definition and features of formation of social responsibility of the organization.

19. Creation of information in the system of social responsibility.

20. Ensuring trust in the organization in the system of social responsibility (International standard ISO 26000:2010, 2010).

Kotler and Lee characterize corporate social responsibility, based on the possibilities of a free choice of a company in favor of the obligation to improve the welfare of the company, implementing appropriate approaches to doing business by using corporate resources (Kotler F., Lee N., 2005).

Bowen focuses on the functional features of corporate social responsibility, determining the directions of policy implementation and decision-making, the implementation of behaviors that are aimed at addressing the goals and values of society (Bowen, 1953). As part of a functional approach, Hrytsyna (Hrytsyna, 2008) characterizes corporate social responsibility through voluntary activities that exceed the statutory requirements for the enterprise and covers environmental, social, labor and economic spheres of responsibility to the environment, society as a whole, local communities, employees, suppliers, consumers, and shareholders.

With the development of a functional approach, the point of view of I. Lebedev deserves attention, which highlights the following elements for the implementation of corporate social responsibility:

- corporate social policy (ensuring productive employment; creating safe and favorable working conditions; adequate wages; improving social and labor relations; strengthening social partnership; development and effective use of human potential; creating a favorable moral and psychological climate; providing social guarantees and additional social package);

- corporate citizenship (promoting the strengthening of the rule of law and civil society, ensuring product quality, respecting the rights and interests of consumers, protecting nature and resource conservation, spreading the traditions of ethical entrepreneurship, developing a social climate; interacting with local authorities and communities, charity and philanthropy; social entrepreneurship; dialogue with the public, the formation of social reporting) (Lebedev, 2014).

Friedman defines corporate social responsibility on its useful characteristics through conducting good business practices (Friedman, 2010). A similar point of view is presented in the works of Grishnova O.A., which considers corporate social responsibility based on the possibilities of forming the social usefulness of its activities to all people and organizations with which it interacts in the process of functioning, and to society as a whole (Grishnova, Dumanskaya, 2011) Carroll (1979). characterizes corporate social responsibility through the prism of economic, legal, ethical, and discretionary expectations that are formed by society in the relevant period. Chernykh (2012) defines corporate social responsibility as the activity of business owners and managers in implementing legally-established norms and voluntarily resolving social issues of society to direct part of the income to support and develop social infrastructure facilities and satisfy the needs of key stakeholders and environmental programs.

It should be noted that in the context of defining corporate social responsibility, researchers describe the following levels:

- corporate - social responsibility of organizations and groups;

- regional - social responsibility of the government subjects of individual regions within one state;

- state - the responsibility of government entities to different groups of stakeholders;

- international - the social responsibility of a set of countries to the world community;

- global - the responsibility of the international community in a globalized world society (Kolot, 2010, 2012). 
A systematic approach to the definition of corporate social responsibility is implemented in Lebedev I.V. (2012). In this work, it is characterized as a system of purposeful and consistent actions of the organization management, aimed at meeting the material and spiritual needs of employees to develop social factors of economic activity and their practical use. The stakeholder approach in determining corporate social responsibility is insisted in (Kolot, 2010, 2012).

\section{Results}

Summarizing the above, the indicators of corporate social responsibility assessment are formed, considering the level of interaction with stakeholders:

1. Formation and implementation of organizational management in the system of corporate social responsibility $\left(\mathrm{CSR}_{1}\right)$.

2. Ensuring human rights $\left(\mathrm{CSR}_{2}\right)$.

3. Creation of labor practices and features $\left(\mathrm{CSR}_{3}\right)$.

4. Providing environmental protection $\left(\mathrm{CSR}_{4}\right)$.

5. Conscientious practices in the system of corporate responsibility $\left(\mathrm{CSR}_{5}\right)$.

6. Solving consumer problems $\left(\mathrm{CSR}_{6}\right)$.

7. Participation in the life of communities and their development $\left(\mathrm{CSR}_{7}\right)$.

8. Recognition of corporate social responsibility $\left(\mathrm{CSR}_{8}\right)$.

9. Identification of stakeholders and interaction with them in the system of corporate social responsibility ( $\left.\mathrm{CSR}_{9}\right)$.

10. Level of organization attitude to corporate social responsibility $\left(\mathrm{CSR}_{10}\right)$.

11. Formation of social responsibility of the organization $\left(\mathrm{CSR}_{11}\right)$.

12. Practical aspects for end-to-end integration of corporate social responsibility $\left(\mathrm{CSR}_{12}\right)$.

13. Exchange of information on corporate social responsibility $\left(\mathrm{CSR}_{13}\right)$.

14. Ensuring increased enterprise confidence regarding corporate social responsibility $\left(\mathrm{CSR}_{14}\right)$.

15. Analysis and modernization of operations and practical activities of the enterprise related to corporate social responsibility $\left(\mathrm{CSR}_{15}\right)$.
16. Development and implementation of a system of corporate social responsibility to ensure interaction with stakeholders $\left(\mathrm{CSR}_{16}\right)$.

17. Formation and implementation of corporate governance in the system of social responsibility $\left(\mathrm{CSR}_{17}\right)$.

18. Ensuring labor relations in the system of corporate social responsibility $\left(\mathrm{CSR}_{18}\right)$.

19. Formation of interaction on the marketing relations formation in accordance with corporate social responsibility $\left(\mathrm{CSR}_{19}\right)$.

20. Ensuring consumer health and safety $\left(\mathrm{CSR}_{20}\right)$.

21. Ensuring sustainable consumption in the system of corporate social responsibility $\left(\mathrm{CSR}_{21}\right)$.

22. Ensuring the protection of information and ensuring the confidentiality of consumers $\left(\mathrm{CSR}_{22}\right)$.

23. Development and interaction with the community in the system of social responsibility $\left(\mathrm{CSR}_{23}\right)$.

24. Ensuring employment in the system of social responsibility $\left(\mathrm{CSR}_{24}\right)$.

25. Formation of modern technologies in the system of social responsibility $\left(\mathrm{CSR}_{25}\right)$.

26. Formation of welfare and income in the system of social responsibility $\left(\mathrm{CSR}_{26}\right)$.

27. Formation of a healthy lifestyle in the system of social responsibility $\left(\mathrm{CSR}_{27}\right)$.

28. Realization of social investments in the system of social responsibility $\left(\mathrm{CSR}_{28}\right)$.

29. Definition and features of the formation of social responsibility of the organization $\left(\mathrm{CSR}_{29}\right)$.

30. Ensuring trust in the organization in the system of social responsibility $\left(\mathrm{CSR}_{30}\right)$.

The system factor that determines the impact of corporate social responsibility of construction enterprises on the formation and implementation of stakeholder interaction (CSR) is assessed based on a model that has the following general form (1).

An economical and mathematical model has been developed for assessing the systemic factor that determines the impact of corporate social responsibility of construction enterprises on the formation and implementation of stakeholder interaction (2):

$$
\begin{aligned}
& \left\{\operatorname{CSR}_{1}, \mathrm{CSR}_{2}, \mathrm{CSR}_{3}, \mathrm{CSR}_{4}, \mathrm{CSR}_{5}, \mathrm{CSR}_{6}, \mathrm{CSR}_{7}, \mathrm{CSR}_{8}, \mathrm{CSR}_{9}, \mathrm{CSR}_{10}, \mathrm{CSR}_{11}, \mathrm{CSR}_{12}, \mathrm{CSR}_{13}, \mathrm{CSR}_{14}, \mathrm{CSR}_{15}, \mathrm{CSR}_{16}\right. \text {, } \\
& \left.C S R_{17}, C S R_{18}, C S R_{19}, C S R_{20}, C S R_{21}, C S R_{22}, C_{S R} 3, C S R_{24}, C S R_{25}, C S R_{26}, C S R_{27}, C_{28}, C S R_{29}, C S R_{30}\right\} \subset C S R \text {, }
\end{aligned}
$$

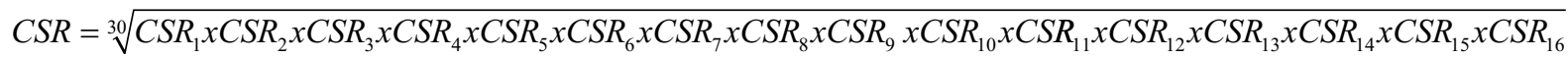

$$
\begin{aligned}
& x \operatorname{CSR}_{17} x \operatorname{CSR}_{18} x \operatorname{CSR}_{19} x \operatorname{CSR}_{20} x \operatorname{CSR}_{21} x \operatorname{CSR}_{22} x \operatorname{CSR}_{23} x \operatorname{CSR}_{24} x \operatorname{CSR}_{25} x \operatorname{CSR}_{26} x \operatorname{CSR}_{27} x \operatorname{CSR}_{28} x \operatorname{CSR}_{29} x \operatorname{CSR}_{30}
\end{aligned}
$$

To determine the factors that show the impact of corporate social responsibility of construction enterprises on the formation and implementation of stakeholder interaction, the method of expert assessments and a scale of values in a range from 0 to 10 are used. Applying the evaluation results and the proposed model, the system factor that determines the impact of corporate social responsibility of construction enterprises on the formation and implementation of stakeholder interaction is evaluated:

$\mathrm{CSR}=2.97$. 
Thus, the insignificant level of formation and implementation of corporate social responsibility is determined, considering the influence of stakeholders on the functioning of construction enterprises.

\section{Conclusions}

Thus, as a result of the study, groups of stakeholders influencing the functioning of construction companies are proposed. The approaches and models that provide control of stakeholder interaction are identified. Based on the generalization of the existing theoretical and methodological provisions for the definition of corporate social responsibility, the indicators of its assessment, which create a quantitative basis for management decisions, are formed. The integral indicator of the formation and use of corporate social responsibility was assessed, taking into account the influence of stakeholders. The insignificant effect of corporate social responsibility on the functioning of construction enterprises has been established. This indicates the need to develop measures to increase the efficiency of the formation and use of corporate social responsibility at construction enterprises and to apply the appropriate strategic directions for ensuring interaction with stakeholders.

According to the results of the research, the directions of increasing the efficiency of stakeholder interaction for the formation and use of corporate social responsibility are proposed:
- increasing the level of effectiveness of interaction with various groups of stakeholders in construction companies;

- strengthening the financial condition of stakeholders;

- increasing the effectiveness of management actions in the system of corporate social responsibility;

- formation and development of human capital with the implementation of conscientious practices in the system of corporate social responsibility;

- implementation of a modern policy on interaction with customers of construction products;

- formation and implementation of a system for assessing corporate social responsibility of construction companies;

- making sound management decisions on the formation and implementation of corporate social responsibility, taking into account the peculiarities of interaction with stakeholders, based on a quantitative basis;

- formation and use of information and analytical support for the implementation of stakeholder policy in the system of corporate social responsibility;

- transition from a local anti-crisis strategy to a strategy for the development of stakeholder relations;

- ensuring the growth of efficiency of social investments of construction enterprises, taking into account the peculiarities of interaction with stakeholders;

- formation and implementation of socially-oriented policy of construction companies.

\section{References:}

Freeman, E. (1984). Strategic Management: A Stakeholder Approach. Boston: Pitman.

D'Anselmi, P. (2011). Values and Stakeholders in an Era of Social Responsibility. New York: Free Press.

Ammari, A. O. (2012). Classification of stakeholders on the basis of mutual views. Actual problems of the economy: Science economical journal, 8, 150-155.

Gatsenko, L. (2016). Stakeholder theories: history of development and problem questions for further research. Vodnij transport, vol. 1, pp. 156-160.

Cleland, D. I. (1998). Stakeholder Management in Jeffrey K. Pinto, (ed.), Project Management Handbook, JosseyBass Publishers.

Nepomnyashchy, O. M. (2013). Socio-economic dimension of the state housing policy in Ukraine. Kharkiv: DokNaukDerzhUpr.

Suslova, V. V. (2011). Functional tasks of self-regulatory organization and their legislative consolidation. The bulletin of Yaroslav Mudryi national law university, vol. 4, pp. 122-130.

Slyusarevsky, N. (2010). Amateur regulation or professional self-government. Mirror of the week: international sociopolitical weekly, vol. 36, p. 6 .

International standard ISO 26000:2010, 2010. Guidance on social responsibility (IDT). ISO 26000 Post Publication Organization. Available at: http://iso26000.info/wpcontent/uploads/2017/02/ISO-26000_and OECD_Guidelines_MNE_PPO_v1.pdf

Kotler F., \& Lee, N. (2005). Corporate social responsibility. How to do as much good as possible for your company and society. Kyiv: Standard.

Bowen, H. R. (1953). Social Responsibilities of the Businessman. New York: Harper \& Brothers.

Friedman, M. (2010). Capitalism and freedom. Kyiv: Spirit and letter.

Plakasov, T. O. (2012). The effectiveness of corporate social responsibility tools. PhD Thesis. Moscow.

Chernykh, O. V. (2012). Management of social responsibility at large enterprises. PhD Thesis. Donetsk.

Hrytsyna, L. I. (2008). The mechanism of formation of corporate social responsibility in enterprise management. PhD Thesis. Kharkiv. 
Grishnova, O. A., \& Dumanskaya, V. P. (2011). Ecological vector of social responsibility. Economics and management, vol. 3, pp. 32-40.

Mamonov, K. A. (2013). Stakeholder strategy of cost-oriented capital management of the brand of construction companies. ScD Thesis. Kharkiv: Kharkiv Academy of Municipal Economy.

Mamonov, K. A. (2011). The organizational-economic mechanism of management stakeholders the building companies: essence, structure and information protection. Komunalne hospodarstvo mist: Naukovo-tekhnichnyy zbirnyk, vol. 100. Series: Economics, pp. 227-234.

Nikitina, L. M. (2013). Classification of stakeholders in the process of forming socially responsible behavior of the company. Available at: www.ncstu.ru

Zub, A. T. (2002). Strategic Management - Theory and Practice. Available at: http://uchebnik-online.com/ soderzhanie/textbook 77. html

Stakeholder. URL: http://ru.wikipedia.org/wiki/

Clarkson, M. E. (1995). A Stakeholder Framework for Analyzing and Evaluating Corporate Social Performance. Academy of Management Review, vol. 20(1), pp. 92-118.

Blair, J. D., \& Fottler, M. D. (1990). Challenges in Health Care Management: Strategic Perspectives for Managing Key Stakeholders. San Francisco: Jossey-Bass.

Savage, G. T., Nix, T. W., Whitehead, C. J., \& Blair, J. D. (1991). Strategies for assessing and managing organizational stakeholders. Academy of Management Executive, vol. 5(2), pp. 61-75.

Mitchell, R. K., Agle, B. R., \& Wood, D. J. (1997). Toward a Theory. Academy of Stakeholder Identification and Salience, vol. 24(4), pp. 853-886.

Doctrine of information security of Ukraine. Decree of the President of Ukraine No 47 of 25.02.2017. Available at: http://www.president.gov.ua/documents/472017-21374

State Service of Special Communication and Information Protection of Ukraine (SSSCIP). State standard of Ukraine. Information protection. Technical protection of information. The main provisions. DSTU 3396.0-96. Available at: http://www.dsszzi.gov.ua/dsszzi/control/uk/publish/article?art_id=38883\&cat_id=38836

Lebedev, I. (2014). Corporate social responsibility: concept and model for Ūkraine. Social and labor relations. Ukraine: Aspects of Labor, 5, 13-19.

Carroll, A. B. (1979). A three-dimensional conceptual model of corporate performance. Academy of Management Review, vol. 4(4), p. 503.

Kolot, A. M. (2012). Social responsibility: theory and practice of development. Kyiv: KNEU.

Kolot, A. M. (2010). Human social responsibility as a factor of stable social dynamics: theoretical principles. Ukraine: Aspects of Labor, vol. 7, pp. 3-9.

Lebedev, I. V. (2012). Social technologies of modern management. Formation of a market economy: Special issue. Strategic imperatives of modern management. Part 2. Kyiv: KNEU.

Savchenko, I. G. (2007). Institutional responsibility of public authorities in the context of building a welfare state in Ukraine. PhD Thesis. Kharkiv: HarRIDU NADU.

Saprykina, M. (2008). The development of CSR in Ukraine. Opinions of the main groups of stakeholders. Corporate social responsibility of business. Expert assessment and practice in Ukraine. Kiev: TEF OLBI. 